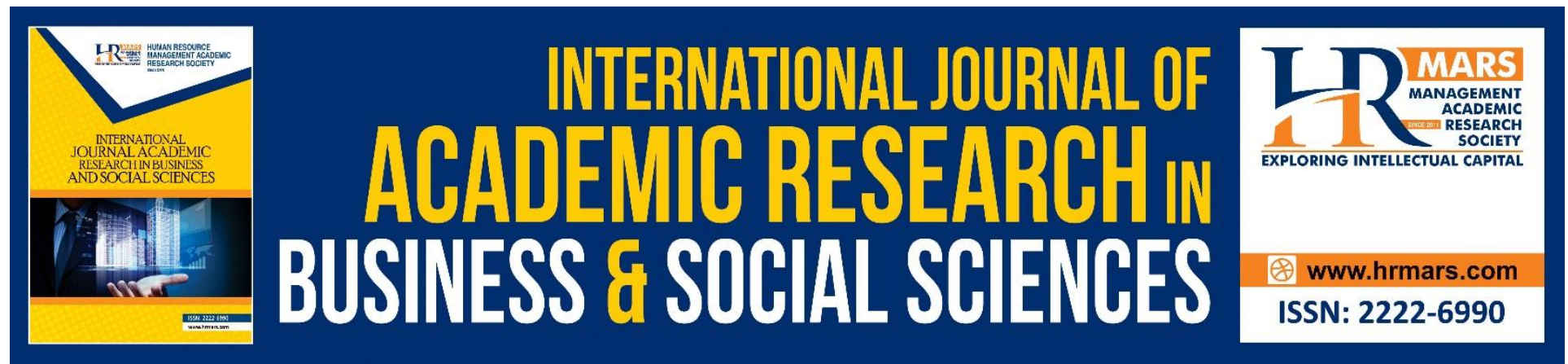

\title{
A Review of Teacher Coaching and Mentoring Approach
}

\section{Zubaidah Bibi Mobarak Ali, Wahiza Wahi, Hamidah Yamat}

To Link this Article: http://dx.doi.org/10.6007/IJARBSS/v8-i8/4609

DOI: $\quad 10.6007 /$ IJARBSS/v8-i8/4609

Received: 21 June 2018, Revised: 18 July 2018, Accepted: 29 July 2018

Published Online: 16 August 2018

In-Text Citation: (Ali, Wahi, \& Yamat, 2018)

To Cite this Article: Ali, Z. B. M., Wahi, W., \& Yamat, H. (2018). A Review of Teacher Coaching and Mentoring Approach. International Journal of Academic Research in Business and Social Sciences, 8(8), 504-524.

Copyright: (C) 2018 The Author(s)

Published by Human Resource Management Academic Research Society (www.hrmars.com)

This article is published under the Creative Commons Attribution (CC BY 4.0) license. Anyone may reproduce, distribute, translate and create derivative works of this article (for both commercial and non-commercial purposes), subject to full attribution to the original publication and authors. The full terms of this license may be seen

at: http://creativecommons.org/licences/by/4.0/legalcode

Vol. 8, No. 8, August 2018, Pg. 504 - 524

http://hrmars.com/index.php/pages/detail/IJARBSS

JOURNAL HOMEPAGE

Full Terms \& Conditions of access and use can be found at http://hrmars.com/index.php/pages/detail/publication-ethics 


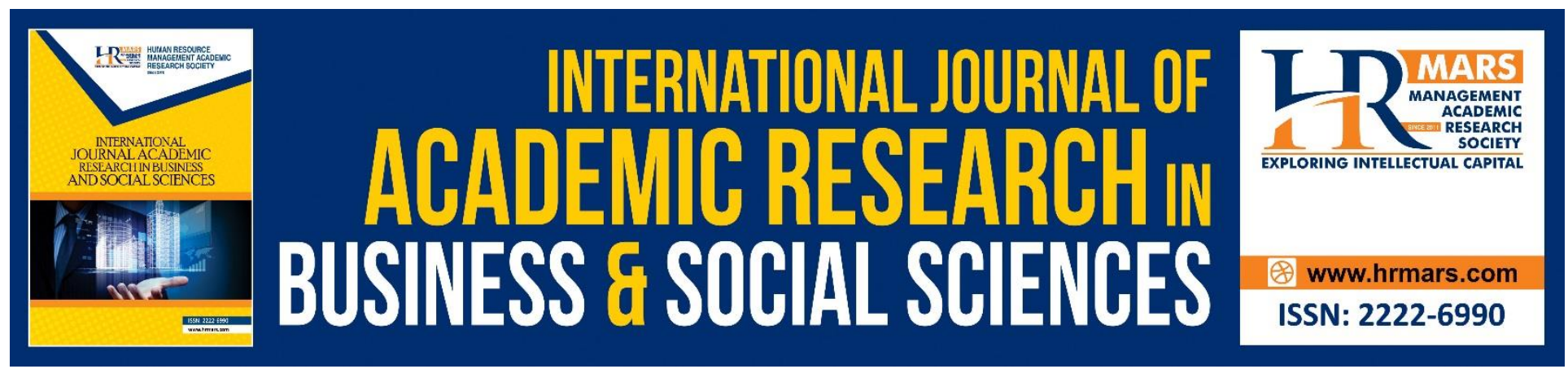

\title{
A Review of Teacher Coaching and Mentoring Approach
}

\author{
Zubaidah Bibi Mobarak Ali \\ Faculty of Education, Universiti Kebangsaan Malaysia \\ Wahiza Wahi \\ Pusat Citra Universiti, Universiti Kebangsaan Malaysia
}

Hamidah Yamat

Faculty of Education, Universiti Kebangsaan Malaysia, Malaysia

\begin{abstract}
This paper presents a review of teacher coaching and mentoring approach in terms of its development in the educational realm, underpinning concepts and implementation for teachers' Continuous Professional Development (CPD). The aim of the paper is to elucidate the competing notions and issues pertinent to the teacher coaching and mentoring approach. A library research on mainstream journals was carried out to find out recent reviews and meta-analyses of teacher coaching and/or mentoring, empirical studies and complemented by online research on the websites of leading coaching and professional development organizations as well as expert consultants, including researchers and authors of key studies. The review indicates gradual patterns of expansion of teacher coaching and mentoring approach that suit a wide range of educational purposes. The review also discloses that teacher coaching and mentoring approach is proven to be a promising practice for teacher learning, teacher change and ultimate improvement in students' achievement. The outcome of the review has implications on future studies on teacher coaching and mentoring approach and the needs for more validations on the effectiveness of such approach to enhance teachers' skills, reflective practice and professional development as a whole.
\end{abstract}

Keywords: Coaching, Mentoring, Teacher, Education, Professional Development, Approach

\section{Introduction}

Students achievement will not improve without making required changes in teachers' classroom practice (Cohen \& Hill, 1998; Kennedy, 2016). Teacher coaching and mentoring approach is believed to be the distinct key lever in improving teachers' classroom instruction and 
translating knowledge into classroom practices (Charner \& Medrich, 2017; Joyce \& Showers, 1996; Kretlow, Cooke, \& Wood, 2012; Neufeld \& Roper, 2003; Pomerantz \& Pierce, 2013). In writing this article, studies that link coaching and specific coaching approaches/models with professional development for teachers were identified and examined. Hence, this paper reviews and summarizes the existing literature on what is known about teacher coaching and mentoring approach as a continuous professional development design in fostering and altering teacher learning. It aims to shed light on the teacher coaching and mentoring approach and inform ongoing efforts to improve the design, implementation and future studies on it.

\section{Evolution of Coaching and Mentoring in Education}

The concept of a 'mentor/ing' emerged in ancient Greece in Homer's Odyssey and as it developed both in myth and reality, while the concept of a 'coach/ing' grew in strength which developed in the disciplines of psychology, business, sports, psychotherapy, counselling, developmental theory, psychology, counselling, management and consultancy theory (National College for Teaching and Leadership n.d.). In the education field, the roots of coaching are traced back to the 1970's and 1980's when educators began to realize that many well-funded programs intended to improve education did not provide the desired changes (Joyce \& Showers, 1996). As a result, Bruce Joyce and Beverly Showers (1980) proposed a job-embedded 'peer-coaching' model that promised to increase the transfer of skills into classroom practice. At this "modeling, practice under simulated conditions, and practice in the classroom, combined with feedback" (B. Joyce \& Showers, 1980, p. 384) were deemed as the most productive training design. At that time, Joyce and Showers became the gurus of 'peer coaching' as a means of staff development. As 'peer coaching' garnered attention in the early 1980's and 1990's, the 'technical coaching model' designed to help teachers transfer what is learned in a workshop environment into the world of the classroom emerged (Cassidy, Garrett, Maxfield, \& Patchett, 2009). At that point in time, most of the staff development practices were also named coaching: 'technical coaching', 'collegial coaching', 'challenge coaching', 'team coaching', and 'cognitive coaching' (Garmston, 1987). Showers and Joyce stipulated that "technical coaching, team coaching, and peer coaching focus on innovations in curriculum and instruction, whereas collegial coaching and cognitive coaching aim more at improving existing practices" (Joyce \& Showers, 1996, p. 14).

Then, in 1997 the 'instructional coaching' applying the partnership principles was introduced by Knight (2007). An instructional coach is one who utilizes effective teaching methodologies and provides on-site professional development training to address the needs of teachers (Denton \& Hasbrouck, 2009; Knight, 2005). In 2003, the Department for Education and Skills (DfES) was already proposing that coaching has the "power to transform teachers' professional learning" (DfES, 2003, p. 23). This was followed by a few other coaching models like 'content-focused coaching' (West \& Staub, 2003), 'literacy or reading coaching' (International Reading Association, 2004) and 'blended coaching' (Bloom, Castagna, Moir, \& Warren, 2005). By the end of 2004, 'literacy or reading coach/ing' was highlighted as a "very hot" topic in the 'Reading Today's 'What's Hot, What's Not for 2005' list (Cassidy \& Cassidy, 2004). The term refered to a professional educator who collaborates with classroom teachers to provide individualized staff development with the aim to improve students' reading and writing skills. In 2005, a framework was documented to clarify the definitions of mentoring and coaching, and identify how best to use both in education (Center for the Use of Research and Evidence in 
Education (CUREE), 2005). They defined three terms in education coaching: 'mentoring' (a structured, sustained process for supporting professional learners through significant career transitions), 'specialist coaching' (a structured, sustained process for enabling the development of a specific aspect of a professional learner's practice) and 'collaborative (co-) coaching' (a sustained process between two or more professional learners to enable them to embed new knowledge and skills from specialist sources in day-to-day practice) (Center for the Use of Research and Evidence in Education (CUREE), 2005, p. 2). In the publication of Leading Coaching in Schools by the National College for School Leadership, Creasy \& Paterson (2005, p. 18) retained the two terms 'specialist coaching and collaborative (co-) coaching' by CUREE and added in another five: 'informal coaching conversations' (short conversations managed in a coaching style), 'team coaching' (group sessions led by an external or expert coach), 'expert coaching' (training in coaching from an experienced externa practitioner), 'pupil coaching' (peer coaching between students), and 'self-coaching' (using a coaching style for self-reflection). In 2006, Sprick introduced 'classroom management coaching' and in 2007, Deussen and colleagues listed five different categories of educational coach: 'data-oriented coaching', 'student-oriented coaching', 'managerial coaching', and two 'teacher-oriented coaching' models, one that works largely with individual teachers and another that works with groups in their research determined.

In 2009, Cornett and Knight identified four approaches to Educational Coaching that are predominantly mentioned in the literature: 'peer-coaching', 'cognitive coaching', 'literacy coaching', and 'instructional coaching'. The growing popularity of 'literacy or reading coaching' was evidenced again in the 2010 'Reading Today's 'What's Hot, What's Not' list where it was listed as a "very hot" topic (Cassidy et al., 2009; Cassidy, Montalvo Valadez, Dee Garrett, \& Barrera IV, 2010); while 'instructional coaching' was said to be the most influential approach by van Nieuwerburgh in 2012. However in 2013, with other issues demanding more attention, the topic was then listed as "very cold" (Cassidy \& Ortlieb, 2013). Although many different models of coaching have emerged in the education field, none of them are meant and "used for evaluation of teachers" (Joyce \& Showers, 1996, p. 14). Nevertheless, a study on teacher coaching and mentoring approach can still be debated as a 'hot' issue.

\section{Coaching vs Mentoring}

There is no single, straightforward answer to define what is coaching as it may take up many forms with different aims, purposes and practices (Creasy \& Paterson, 2005). However, The International Coach Federation (ICF) (2005, p. 1) provided a broadly acceptable definition of coaching as a "professional partnership between a qualified coach and an individual or team that support the achievement of extraordinary results, based on goals set by the individual or team". Synthesizing the definition of coaching from various sources, Wilkins (2000, p. 5) defined coaching as "one-on-one relationship where a coach supports, collaborates with, and facilitates an individual's learning by helping the individual to identify and achieve future goals through assessment, discovery, reflection, goal setting and strategic action". Concurring to it, Hamlin, Ellinger and Beattie (2008, p. 291) defined coaching as "the explicit and implicit intention of helping individuals to improve their performance in various domains, and to enhance their personal effectiveness, personal development, and personal growth". Michael (2008) stipulated that coaching is generally more structured in nature and meetings are often scheduled on a 
regular basis. Building on these definitions and focusing on coaching in education, van Nieuwerburgh (2012, p. 17) provided a more detailed definition of coaching:

one-to-one conversation focused on the enhancement of learning and development through increasing self-awareness and a sense of personal responsibility, where the coach facilitates the self-directed learning of the coachee through questioning, active listening, and appropriate challenge in a supporting and encouraging climate.

According to National College for Teaching \& Leadership (2013), coaching is a time-bound, formal intervention focused on shorter-term goals and challenges. Recently, Beattie and colleagues (2014, p. 186) proposed that coaching helps individuals with the performance and development of certain skills through some form of "facilitation activity or intervention".

Mentoring on the other hand is a continuing but informal relationship focused on longterm goals (National College for Teaching \& Leadership, 2013). It needs not be a formal process and meetings can take place as and when the individual needs some advice, guidance or support (Fielden, 2005). A mentor is usually a more experienced colleague; someone very familiar with a particular culture and role, who has influence and can use his experience to help an individual analyse his situation in order to facilitate professional and career development (Center for the Use of Research and Evidence in Education (CUREE), 2005). It is rather an ongoing relationship based activity with several specific but wide ranging goals. The mentor works with either an individual or a group of people over an extended period of time. Mentoring seeks to develop the individual professionally with the ability to apply skills, knowledge and experience to new situations and processes (Michael, 2008). Within mentoring relationships, emotional support is a key element. Individuals develop and learn through conversations with mentors who share knowledge and skills that can be incorporated into their thinking and practice (Wong \& Premkumar, 2007). Mentoring relationships are also often described as coaching (Poglinco et al., 2003).

Coaching and mentoring can be 'stand alone' activities, but they can also be used to complement each other. Department for Education and Skills (DfES) 2003, Rogers (2008) and, Weiss and Kolberg (2003) pointed out that coaching and mentoring are very similar in common, where the activities shade into each other using very much the same practices, values, skills and competencies. This is futher supported by Knight (2004), stating that coaching roles often involve a delicate balance between mentoring responsibilities and whole-school improvement or system-wide professional development. At the same time, most of the skills required in a coach or a mentor are also similar. Both coaches and mentors need to be good listeners, ask powerful questions and encourage their clients to pursue their ambitions and aspirations (van Nieuwerburgh, 2012). Apparently, literature also uses the terms 'coaching and mentoring' interchangebly so that coaching and formal mentoring are similar in nature but different in name (Joo, Sushko, \& McLean, 2012).

\section{Coaching Approaches in Education}

Coaching approaches in education can be presented with a variation in focus, duration and setting (Aikens \& Akers, 2011). Deussen et al. (2007) in their research determined five distinct categories of educational coach: data-oriented, student-oriented, managerial, and two teacher- 
oriented categories, one that works largely with individual teachers and another that works with groups. Data oriented coaching focuses on data and assessment-related tasks to facilitate the connections between data and instruction. Student-oriented coaching focuses directly with students rather than teachers. Managerial coaching focuses in managing systems within schools such as facilitating meetings and keeping up with paperwork. Teacher-oriented coaching focusses on supporting teachers individually and in small groups.

Aguilar (2013a) listed three distinct types of coaching models: directive (or instructive) coaching, facilitative coaching and transformational coaching. Directive coaching focusses on changing teachers' behaviors. The directive coach shows and shares her expertise by providing resources, making suggestions, modelling lessons and teaching how to do something but it seldom results in sustainability or internalization of learning. Facilitative coaching focusses on teachers learning new ways of thinking and being through reflection, analysis, observation and experimentation. The teachers' awareness on the importance to learn those new ways influences their behaviors. The facilitative coaches avoid sharing expert knowledge but work in building on their existing skills, knowledge and beliefs to construct new skills, knowledge and beliefs that will form the basis for future actions. A foundation for facilitative coaching is cognitive coaching as they both focuses on exploring and changing the way the teachers behave by encouraging reflective practices and guiding teachers towards self-directed learning. Facilitative coaching is also influenced by ontological coaching as it focuses on exploring how the teachers' perceptions and attitudes influences their behavior and communication. Lastly, transformational coaching draws from ontology, incorporating strategies from directive and facilitative coaching, as well as cognitive and ontological coaching. Transformational coaching aims to change: (a) the teachers' behaviors, beliefs and being; (b) the schools in which the teacher works and the other teachers, students and administrators who are in the same school and (c) the broader educational or social systems. Aguilar (2013a) concluded by stating that this kind of coaching only works when the coach is engaged in a process of transforming his own behaviors, beliefs, and being, along with the teachers'.

Other researchers has focused on directive coaching, reflective or responsive coaching and a balanced combination of directive and reflective coaching (Borman, Feger, \& Kawakami, 2006; Coburn \& Woulfin, 2012; Deussen et al., 2007; Heineke, 2013; Ippolito, 2010). Directive coaching is where the coach leads as an expert and focuses on predetermined practice or strategy whereas reflective or responsive coaching is where the coach and teacher engage collaboratively in coaching for reflection and the focus is teacher-centered. Some of these researchers position directive and reflective coaching as a black-and-white dichotomy (Coburn \& Woulfin, 2012; Deussen et al., 2007). However, the balance between both is believed to be most conducive to providing learning to teachers by building supportive relationships and simultaneously giving concrete suggestions about instructional practices that may enhance students' learning (Heineke, 2013; Ippolito, 2010).

To discuss the responsive and directive coach-teacher relationships, Ippolito (2010) conducted grade-level focus groups interview with 24 coaches. The coaches categorized coaching as being either directive or responsive. They identified three ways of working as successful mechanisms for providing combined pressure and support: "(a) shifting between responsive and directive moves within a single coaching session; (b) using protocols to guide individual and group coaching sessions; and (c) sharing leadership roles to align teacher, coach, and administrative 
goals" (Ippolito, 2010, p. 169). The coaches reported that by balancing responsive and directive coaching, it allowed them to build supportive relationships with teachers and simultaneously make suggestions about instructional practices. Similarly, in another study investigating the role of coaches in the implementation of Reading First policy in USA, Coburn and Woulfin (2012), denoted that coaches influenced teacher learning and teacher change not only by providing support but also through pressuring and persuading. Undoubtedly, teachers responded more positively to persuasion rather than pressuring. The coaches in this study also played a "key gatekeeping role" to advice teachers on the policy aspects of Reading First (Coburn \& Woulfin, 2012, p. 23). The study concluded by stating that the coaches used both the educative and political roles to mediate between Reading First policy and teachers' classroom practice.

However, Heineke (2013) in examining coaching discourse, conducted both an interpretive and structural analysis. She found that during one-to-one sessions, coaches showed a tendency to dominate the discourse by initiating $70 \%$ of the exchanges, offering $80 \%$ of the suggestions for later actions and contributing $65 \%$ of the total utterances. The study suggested that stakeholders should do their part in helping coaches to stay focused on the coaching goal of facilitating teacher learning in order to increase student achievement. For productive coaching to occur, coaches must respect, listen and build credibility with teachers, make themselves always available and visible among teachers, and maintain the trust/confidentiality with teachers (Heineke, 2013). Hunt and Handsfield (2013) investigated the experiences of first year literacy coaches and their negotiation of power as they are participating in literacy coach professional development and providing professional development opportunities to teachers. Data collection methods were two 60-minutes semi-structured interviews, observations, and artifacts (samples from participant reflection journals, documents from training sessions, and information about assignments) from five professional development sessions. The study concluded by suggesting coaches need quality professional development opportunities that include conversation around the emotional aspects of the coaching position.

Many other researchers have described several distinct approaches with unique goals and methods like, classroom management coaching (Sprick, 2006), content-focused coaching (West \& Staub, 2003) and blended coaching (Bloom et al., 2005). According to Cornett and Knight (2009), coaching approaches that are still common in today's education systems are peer coaching (Joyce \& Showers, 1996), literacy coaching (Toll, 2014), cognitive coaching (Costa \& Garmston, 1994) and instructional coaching (Knight, 2007). It is critical to recognize that regardless of the form that coaching takes, they have been described with the same goal of having a knowledgeable other (the coach) collaborating with the teacher to provide individualized development which will impact on student learning (Cassidy et al., 2009). In common it is a "three-part process": pre-lesson discussion between the coach and the coached teacher followed by an observation of classroom practice of the coached teacher by the coach, and a post-lesson discussion to discuss and analyze what had been observed (Department for Education and Skills (DfES 2003, p. 7).

Lloyd and Modline (2012:3) listed the common features among the models of coaching: (a) building relationship with teachers; (b) observing, modeling and advising in the classroom; (c) discussing classroom practices with teachers, provide support and feedback, and assist with problem-solving for classroom challenges; and (d) monitoring progress towards identified goals. They also emphasized that this form of professional development differs from the typical 
education professional development, which generally consists of 'one-shot' activities with denial for exploration of the breadth or depth of any particular topic (Lloyd \& Modline, 2012). Often, in most of the education system, full-time coaches are hired to provide on-site coaching and mentoring as components of job-embedded Continuous Professional Development (CPD) for teachers.

\section{Coaching and Mentoring as CPD for Teachers}

In this rapidly changing world, the expectations placed upon teachers are evolving too (Hazri, Nordin, Reena, \& Abdul Rashid, 2007). Teachers today need to not only assimilate academic knowledge but also to incorporate knowledge derived from experiential and practical experiences in the classroom. They have to cater the needs of students from diverse racial, ethnic and socio-economic backgrounds, and students who range in interests, abilities and proficiency (Kaur, 2017). They have a crucial role to play in improving and maintaining the academic performance of students, thus they must possess and maintain the relevant competences required to be effective in today's classrooms (Hazri et al., 2007). The evolutionary nature of education with reforms of competency and performance-based teacher evaluation instrument that includes student test scores, adoption of higher academic standards, and the development of high stakes standardized tests aligned with these new standards; demands teachers to be lifelong learners.

Since teachers are required to teach using a variety of new methods that they themselves have not experienced as students (Nelson \& Hammerman, 1996), helping them to learn, unlearn and relearn their current beliefs about students and instructions is essential for them to make shifts in their thinking and instructional practice (Darling-Hammond \& McLaughlin, 1995). As said by the leader of Measures of Effective Teaching (MET) Project, Professor Tom Kane, "If we want students to learn more, teachers must become students of their own teaching. They need to see their own teaching in a new light" (in Bill \& Melinda Gates Foundation, 2013, p. 2). Teachers need to be enlightened with deep content knowledge, challenging pedagogical skills, advance technology developments and technique to cater for more individualized teaching and special learning needs through differentiated teaching and learning. Research also shows that teachers from countries that are top performers in PISA (Program for International Student Assessment) and TIMSS (The IEA's Trends in International Mathematics and Science Study) have more opportunities to learn content, pedagogical content and general pedagogy (Ministry of Education (Malaysia), 2013). So, it is critical to create opportunities for both novice and experienced teachers to grow and develop in their practice so that they, in turn, can help students grow, develop their knowledge, be creative and have the ability to think critically. This is where the delivery of the best researched proven teacher learning platform - Professional Development (PD) operates (Colbert, Brown, Choi, \& Thomas, 2008; Hassel, 1999a; Snow, Griffin, \& Burns, 2005).

Research by Hattie (2012), Kempton (2013) and Rand Education (2012) state that the teacher factor is vital for students' achievement and according to the National Staff Development Council (2001), PD is imperative in enhancing teacher quality and raising students' achievement. PD creates opportunities for teachers to further enhance their professionalism in all aspects relevant to their knowledge, skills and the professional context of their career (Emery, 2013; Zein, 2016). According to Snow, Griffin and Burns (2005), ongoing PD and support are significant to 
guarantee that all teachers know how to execute magnificent literacy instruction. Hassel (1999) defined PD as the process of improving teacher skills and competencies needed to produce outstanding students' achievements.

There are a variety of PD opportunities centered on teaching the curriculum, using strategies for collaborative learning, adopting new subject-matter approaches and innovative pedagogical practices, managing student learning, integrating assessment with curriculum, and implementing strategies to reach the diverse learners which teachers can utilize to implement change (Ganser, 2000). In addition, there are also many types of PD approaches used to relate all those knowledge and skills: informal dialogue sessions, courses and workshops, reading professional literature, education conference and seminars, professional development network, qualification programs, individual and collaborative research (OECD, 2009). However, it is not just about providing PD but also providing effective in situ job-embedded PD. Availability alone is not an issue but the impact of it, is. Teachers reported that the most needed learning necessities are often denied when engaging in these traditional forms of PD, so much so that they turn to be totally useless (Darling-Hammond et al., 2009; Fullan, 2007; Knight, 2007). This is mostly because these type of PD are short in duration, lacks intellectual level, and has poor focus with little substantive research-based content (Kent, 2004). Research states that traditional one-stop workshops and go-away professional conferences lack a direct link to improvement of teachers' instructional practices in their unique teaching environment (Bolton, 2007) because teachers just hear about great practices and don't receive follow-up support (Knight, 2009). The existing PD programs which mostly use the cascade model, are unable to tailor the instructional approaches to meet the needs of students, time consuming, lacking in follow-up support and do not promote collaboration (Pang \& Wray, 2017; Radzuwan, Shireena Basree, \& Kamariah, 2017; Senom, Razak Zakaria, \& Sharatol Ahmad Shah, 2013). Thus, the real issue is not that teacher are not given the opportunity to attend PD, but the typical forms of PD often miss the real focus on student achievement.

Research by Center for the Use of Research and Evidence in Education (CUREE) (2012) proves that there is a close relationship between the design and content of teachers' PD delivery and the professional learning experiences of teachers. Despite having an appalling track record in its productiveness (Yoon, Duncan, Lee, Scarloss, \& Shapley, 2007), workshop is still the most popular model chosen for delivering PD in many countries. The best PD should not only keep teachers up-to-date on the latest education-related research, teaching technology tools, curriculum reforms and resources, but it should also be ongoing, experiential, collaborative, and connected to and derived from working with students (Edutopia, 2008). Colbert (2008) stated that improving teacher quality depends on improving PD and improving PD depends on creating meaningful learning experiences for teachers that include attributes of coaching and mentoring, peer observation, networking and collaborative work. Currently, teachers demand to be offered job-embedded on-going support and one such support that is showing great promise for improving instruction is school-based coaching and mentoring (Knight, 2007; Sailors \& Shanklin, 2010).

In one study, Guskey (2003) analyzed 13 of the most famous lists of the characteristics of PD. He then, listed 21 characteristics that were deemed important for high-quality PD. The three most prominent and frequent characteristics were enhancement of teachers' content and pedagogical knowledge, time and resources, and, collegiality and collaboration. These 
characteristics were noted as impacting PD because they had an impact on teacher quality. In another research by CUREE (2012), they emphasized on four effective CPD approaches: collaborative enquiry, coaching and mentoring, collaborations within and between school, and using structured dialogues and group work for teachers to try out new approaches. These studies prove that coaching and mentoring is an essential component of an effective PD program or 'teacher learning' (R. Smith \& Lynch, 2014) as it provide "tailor-made in-schools strategies collaborative, sustained, embedded in real life learning context and supported by specialists" (Lloyd \& Modline, 2012, p. 221). Aguilar (2013a, p. 8) adds "coaching can build will, skill, knowledge and capacity because it can go where no other PD has gone before: into the intellect, behaviors, practices, beliefs, values and feelings of a teacher". Supported further by Toll (2014), coaching is a partnership, collaboration between equals; is job-embedded; is about professional learning; supports reflection about students, the curriculum and pedagogy; and leads to better decisions. Researchers confirmed that teachers who actively engaged in coaching tried new instructional practices learned in traditional workshops more often than teachers who did not (Knight, 2004; Neufeld \& Roper, 2003; Sailors \& Price, 2015; Vanderburg \& Stephens, 2011). Thus, as a strong alternative to the ineffective traditional PD methods, coaching is increasingly being advocated in many countries' education system.

Annenberg Foundation for Education Reform conducted a study on coaching in 2014 and reported that coaching is a promising element of effective professional development in the following ways (King et al., 2014):

a) Effective coaching encourages collaborative, reflective practice. Coaching allows teachers to apply their learning more deeply, frequently, and consistently than teachers working alone. Coaching supports teachers to improve their capacity to reflect and apply their learning not only to their work with students, but also to their work with each other (Neufeld \& Roper, 2003). This is consistent with Joyce and Showers (1996, p. 13) findings that groups of teachers "...developed skills in collaboration and enjoyed the experience so much that they wanted to continue their collegial partnerships after they accomplished their initial goals".

b) Effective embedded professional learning promotes positive cultural change. The conditions, behaviors, and practices required by an effective coaching program can affect the culture of a school or system, thus embedding instructional change within broader efforts to improve school-based culture and conditions (Neufeld \& Roper, 2003).

c) Effective coaching encourages the use of data analysis to inform practice. Effective coaching programs respond to needs suggested by data, allowing improvement efforts to target issues such as closing achievement gaps. A coaching program guided by data helped create coherence within a school (Barr, Simmons, \& Zarrow, 2003) by focusing on strategic areas of need that are suggested by evidence, rather than by individual and sometimes conflicting opinions.

d) Coaching promotes the implementation of learning and reciprocal accountability. Coaching is an embedded support that attempts to respond to student and teacher needs in ongoing, consistent, dedicated ways. The likelihood of using new learning and sharing responsibility rises when colleagues, guided by a coach, work together and hold each other accountable for improved teaching and learning (Barr et al., 2003). And because instructional coaching takes place in a natural setting of the classroom, observation, learning, and reflection can occur in real situations (Neufeld \& Roper, 2003). 
e) Coaching supports collective leadership across a school system. An essential feature of coaching is that it uses the relationships between coaches, principals, and teachers to create the conversation that leads to behavioral, pedagogical, and content knowledge change. Effective coaching distributes leadership and keeps the focus on teaching and learning. This focus promotes the development of leadership skills, professional learning, and support for teachers that target ways to improve student outcomes.

Nevertheless, continuous innovation in CPD programs is required to improve teacher workforce. Teacher coaching and mentoring approach is the promising approach that can provide a flexible blueprint for these efforts (Kraft, Blazar, \& Hogan, 2018).

\section{Conditions for Success in Educational Settings}

Many scholars have listed several critical conditions that need to exist to some degree for a coach to effectively partner with teachers and support them in developing their practice (Aguilar, 2011a, 2011b; Bean, Draper, Hall, Vandermolen, \& Zigmond, 2010; Boller et al., 2010; Bredeson, 2000; Charner \& Medrich, 2017; Elish-Piper \& L'Allier, 2011; Heineke, 2013; Knight, 2009; Matsumura, Sartoris, Bickel, \& Garnier, 2009; Ng, Choong, Norizan, Lam, \& Siti Mariam, 2014; Sarabiah \& Zamri, 2016; R. E. Smith, 2009; Taylor, Zugelder, \& Bowman, 2013; The Wallace Foundation, 2013; Vikraman, Mansor, \& Hamzah, 2017). Aguilar (2011b) states clearly that coaching can be very challenging if any of the conditions are completely missing. The researchers associated with the 2005-2008 Kansas Coaching Project at the University of Kansas Center for Research on Learning, have listed out the seven factors that repeatedly appeared to be critical for coaching success when they worked with coaches and other educators in schools, districts and state agencies in more than 35 states (Knight, 2009):

a) Focus and continuity - Policy makers and education authorieties should not adopt and abondon too many education programs and initiatives as it will only cause teachers to loose interest in teaching. To create a better platform for teachers' CPD, only a few high-leverage strategies should be sustained.

b) A learning-friendly culture - The place where teachers work, the school, should be a place where they are respected, free to take risks, away from unnecessary punishments (Knight, 2009), and a safe learning environment (van Nieuwerburgh, 2012). This is because teachers who work in learning-friendly schools tend to collaborate more with the coaches. Aguilar (2011b) states that the school culture needs to be oriented towards growth and improvement. Both teachers and administrators, need to be eager to learn and improve their practice when given support.

c) Principal support - In order for coaching to be effective, there should be a close partnership between the coach and the principal (Aguilar, 2011b; Matsumura, Garnier, \& Resnick, 2010). They should work closely on implementing whole-school initiatives and identifying the needs of the teachers (Charner \& Medrich, 2017). Principals should take part in coaching workshops conducted by the coach, observe coaches while they conduct model lessons, speak frequently to the teachers on the importance of professional development opportunities and coaching, learn what the coach shares with teachers, and frequently meet the coches to ensure their vision for professional development is being accomplished (Knight, 2009a, p. 19). Bredeson (2000) states that principals must take note of what and why changes are being asked of the teacher, as they have great influence on teachers' professional development or teacher 
learning (Bredeson, 2000; R. E. Smith, 2009; The Wallace Foundation, 2013). Studies conclude that principal's understanding, influence and support are important factors for a fruitful coaching and mentoring session (Ng et al., 2014; Sarabiah \& Zamri, 2016; Taylor et al., 2013; Vikraman et al., 2017) as they can be the key to closing the gap between teachers and coaches by providing supportive working environments and, allocating sufficient time and resources (Aguilar, 2011b; Knight, 2009).

d) Clear roles - Coaches should ensure that they work as peers with the teachers providing sufficient support for professional development, while principals and other administrators should respectfully hold the teachers accountable. Teacher evaluation tasks should only be done by the principals or other administrators. A teacher's willingness to collaborate and implement strategies suggested by the coach may depend on that teacher's confidence in the coach (ElishPiper \& L'Allier, 2011). Thus, coaches should play a role of on-site professional developers empowering teachers to incorporate research-based instructional methods into their classrooms (Knight, 2007).

e) Protect the coaching relationship - Coaching works best when teachers are collaborating with the coach because they want to and not because they are forced to. Thus, principal should present coaching as an "effectiveness builder" and not a "deficit-filler" (Aguilar, 2011a). It is important for a principal to explain to the teachers on why a coach is coming to the school, what the coach is supposed to do and how teachers are expected to work with the coach to avoid further complications and to support coaches. They should encourage the teachers to perceive the coach as a lifeline rather than a punishment (Knight, 2007).

f) Time - Coaches should spend much of their time on coaching. The education authorities, state and district leaders need to ensure that the coaches are not burdened with too many noncoaching tasks that they end up having no time for sustained coaching. Although the amount of time coaches spend working directly with teachers were significant predictors of student gain as said by Elish-Piper and L'Allier (2011), and Bean and colleagues (2010), it was also a critical challenge for coaches (Bean et al., 2010; Boller et al., 2010; Taylor et al., 2013). These studies have attempted to highlight factors that may affect the efficacy of coaching efforts in relation to the amount of time devoted to and available for coaching. Coaches in two communities in Washington State described several challenges associated with completing coaching visits. These include holidays, vacations, classroom activities, and other commitments, such as attending trainings and conferences (Boller et al., 2010). In another study, 12 coaches stated that management activities like technical issues related to online course required by PDF, handling problems like arranging for substitutes, or writing reports for the administration took an exorbitant amount of their time from coaching activities. This study also concluded by saying that when a coach spends more time on school management or administrative tasks, it diminishes the value of the coach in the eyes of the teachers. Teachers had negative perceptions on coaches who spend more time on management tasks (Bean et al., 2010). A concept paper analyzed four different studies conducted in USA. Coaches were expected to spend $50 \%$ of their time on in modeling instruction, direct coaching and coach-teacher conferences. But then a study in 2011 by Bowman (as cited in R. T. Taylor et al., 2013) found that the mean percentage of time that the middle school coaches reported to have spent in these activities totaled $35.68 \%$ and the mean time high school coaches reported to have spent in such activities was 32\% (Boulware, 2006 as cited in R. T. Taylor et al., 2013). This mean of percentage of time was markedly lower that the 
$50 \%$ of time explicitly requested of the coaches. These findings indicated that over the four years between the two studies, progress had not been made toward meeting the role expectation related to use of the coaches' time (Taylor et al., 2013). In conclusion, the quality and effectiveness of coaching may be affected by lack of time.

g) Continuous learning - Coaches and administrators should continuously improve their own professional practice. Coaches need to be given the opportunities to gain a better understanding of the practices or content knowledge that they share with teachers as well as the coaching practices and communication skills that are necessary for effective coaching. This was similarly agreed by Heineke (2013) who studied the coaching interactions of four coaches and four teachers from four different schools. Knight (2009a) added that principals need to know how they can contribute to conditions that support effective coaching. Thus, both, coaches and principals needs CPD and also to be coached so that they are constantly learning and improving the way they lead instructional improvements in schools (Aguilar, 2011b; Knight, 2009).

\section{Conclusion}

There is a considerable amount of literature that addresses the notion of teacher coaching and mentoring approach and it is proven to be a promising practice for teacher learning, teacher change and ultimate improvement in student achievement (L'Allier, Elish-Piper, \& Bean, 2010). It is believed to be the best job-embedded, on-the-ground CPD strategy in raising teaching standards by enhancing teachers' knowledge and skill, in understanding and executing the latest education reforms, curriculum, pedagogy and assessment strategies. Undertaking this review of the literature has demonstrated that it is essential for affiliated stakeholders to take fundamental and practical actions to design effectual CPD for teachers. To bolster more effective implementation of the coaching approach, they need to assess the readiness of the community in adopting the innovation and ensure that the organizational structures are in place to support the innovation (Matsumura, Garnier, \& Resnick, 2010).

Principals and district leaders should not only support but also act as partners in coaches' work so that they can establish a shared vision of successful coaching. They should be eager and willing to learn effective ways to support their coaches' work with teachers (Aguilar, 2011b; Matsumura, Garnier, \& Resnick, 2010). As teachers often too busy to participate in coaching (Boller et al., 2010; Dewitt, 2014; Jao, 2013; Matsumura, Garnier, \& Resnick, 2010; Westman, 2016), steps should be taken to ensure that the program is not "one more thing" added to their schedules (Matsumura, Garnier, \& Resnick, 2010, p. 268). The roles of the coach and the teacher should be made clear to support an effective execution of the coaching program. Teachers, on the other hand need to take the necessary steps to learn, unlearn, relearn and implement effective practices that promises student achievement. Collaboration with coaches ensures professional development will no longer be futile, instead best practices will take root and all the hard work of teachers will not be in vain. Both, the teacher and the coach must take must take active roles in sharing understandings and building trusted collaborative relationships.

It is important to note the diverse studies pertinent to the coaching issues such as the impact of coaching on teachers and their instructional practice (Ahmad Syahiran, Radzuwan, Kamariah, \& Safawati Basirah, 2016; Charner \& Medrich, 2017; Matsumura, Garnier, Correnti, Junker, \& DiPrima Bickel, 2010; Medrich, Fitzgerald, \& Skomsvold, 2013; Neuman \& Wright, 2010), the impact of coached teachers on student engagement and student learning (Charner \& 
Medrich, 2017; Matsumura, Garnier, Correnti, et al., 2010; Sailors \& Price, 2015), the impact of coaches on student achievement (Bean et al., 2010; Elish-Piper \& L'Allier, 2011; Medrich et al., 2013; Porche, Pallante, \& Snow, 2012; Taylor et al., 2013), how coaches spent their time (Israel, Kamman, McCray, \& Sindelar, 2014; Taylor et al., 2013), teachers' perceptions of their coaches (Israel et al., 2014; Mohd Hilmi \& Jamil, 2017; Taylor et al., 2013; Vanderburg \& Stephens, 2011), relationship between what coaches do and what teachers change (Heineke, 2013), the role of administrators in coaching (Charner \& Medrich, 2017; Matsumura et al., 2009; Vikraman et al., 2017); Professional Learning Community (PLC) practices with coaches (Bitty \& Pang 2016, 2017; Suzalin et al. 2016). Notwithstanding these heterogeneity, literature seeks for more evidence in each of the aforementioned areas as well as other relevant areas (Ahmad Syahiran et al., 2016; Borman et al., 2006; Fielden, 2005; Li \& Chan, 2007; Mohd Hilmi \& Jamil, 2017; Sailors \& Price, 2015; R. Smith \& Lynch, 2014; Taylor et al., 2013). In summary, although for years many have valued the great potential of the coaching and mentoring approach, the literature suggests it remains as a growing field in education to be researched on (Bitty \& Pang, 2016; Desimone \& Pak, 2017; Fielden, 2005; Gallucci, DeVoogt Van Lare, Yoon, \& Boatright, 2010; Knight, 2007; Lowenhaupt, Mckinney, \& Reeves, 2014; Mohd Hilmi \& Jamil, 2017; Taylor et al., 2013). This is especially important in order to validate that it is the most successful approach for embedded learning and application of skills, reflective practice, and professional development.

\section{Acknowledgement}

I sincere acknowledge to my Supervisors Assoc. Prof. Dr. Hamidah Yamat and Dr. Wahizah Wahi for their constant support, guidance and encouragement to embark and complete this paper. My sincere acknowledgement to Dr. Nurul Fadly Habidin (UPSI) and post-graduate academic partner Sharmini Siva Vikaraman (UKM) for their kind contributions towards completing this paper.

\section{Corresponding Author}

Zubaidah Bibi Mobarak Ali, Faculty of Education, Universiti Kebangsaan Malaysia, Malaysia. Email: ikazubaidahali@gmail.com 
INTERNATIONAL JOURNAL OF ACADEMIC RESEARCH IN BUSINESS AND SOCIAL SCIENCES

Vol. 8, No. 8, August 2018, E-ISSN: 2222-6990 @ 2018 HRMARS

\section{References}

Aguilar, E. (2011a). Coaching Teachers: What You Need to Know. Education Week Teacher.

Retrieved from http://www.edweek.org/tm/articles/2011/02/15/

Aguilar, E. (2011b, May). Instructional Coaching: Four Conditions Essential for Instructional Coaching to Work.

Aguilar, E. (2013). The Art of Coaching : Effective Strategies for School Transformation (First). San Francisco: Jossey-Bass.

Ahmad Syahiran, M., Radzuwan, A. R., Kamariah, Y., \& Safawati Basirah, Z. (2016). Exploring the School Improvement Specialist Coaches' Experience in Coaching English Language Teachers. Arab World English Journal, 7(3), 271-285.

Aikens, N., \& Akers, L. (2011). Background Review of Existing Literature on Coaching: Final Report. Ansawi, B., \& Pang, V. (2017). The Relationship between Professional Learning Community and Lesson Study: A Case Study in Low Performing Schools in Sabah, Malaysia. Sains Humanika, 9(1-3), 63-70. Retrieved from http://www.sainshumanika.utm.my

Barr, K., Simmons, B., \& Zarrow, J. (2003). School Coaching in Context: A Case Study in Capacity Building. Annual Meeting of the American Educational Research Association (Chicago, IL, April 21-25, 2003).

Bean, R. M., Draper, J. A., Hall, V., Vandermolen, J., \& Zigmond, N. (2010). Coaches and coaching in reading first schools: A reality check. The Elementary School Journal, 111(1), 87-114. https://doi.org/10.1086/653471

Beattie, R. S., Kim, S., Hagen, M. S., Egan, T. M., Ellinger, A. D., \& Hamlin, R. G. (2014). Managerial Coaching: A Review of the Empirical Literature and Development of a Model to Guide Future Practice. Advances in Developing Human Resources, 16(2), 184-201. https://doi.org/10.1177/1523422313520476

Bill \& Melinda Gates Foundation. (2013). Measures of Effective Teaching Project Releases Final Research Report. Findings Help Inform Design and Implementation of High-Quality Feedback and Evaluation Systems. Measures of Effective Teaching (MET) Project. Phoenix.

Bitty, A., \& Pang, V. (2016). Professional Learning Community Practices among Teachers in SISC+ Program in Low Performing Schools in Sabah, Malaysia. International Journal of Administration and Governance, 2(1), 19-24. Retrieved from http://www.iwnest.com

Bloom, G., Castagna, C., Moir, E., \& Warren, B. (2005). Blended coaching : Skills and Strategies to Support Principal Development. SAGE Publications.

Boller, K., Del Grosso, P., Blair, R., Jolly, Y., Fortson, K., Paulsell, D., ... Kovac, M. (2010). The Seeds to Success Modified Field Test: Findings from the Impact and Implementation Studies. Mathematica Policy Research, Inc.

Bolton, M. V. (2007). READING COACHES AS AN IN-CLASS PROFESSIONAL DEVELOPMENT MODEL. The Reading Matrix, 7(2), 46-63.

Borman, J., Feger, S., \& Kawakami, N. (2006). Instructional Coaching: Key Themes from the Literature. The Education Alliance Brown University (Vol. Winter). Providence : RI. Retrieved from www.alliance.brown.edu

Bredeson, P. V. (2000). The school principal's role in teacher professional development. Journal of In-Service Education, 26(2), 385-401. https://doi.org/10.1080/13674580000200114

Cassidy, J., \& Cassidy, D. (2004). What's hot, what's not for 2005. Reading Today, 22(3), 1-9. Retrieved from http://search.ebscohost.com 
INTERNATIONAL JOURNAL OF ACADEMIC RESEARCH IN BUSINESS AND SOCIAL SCIENCES

Vol. 8, No. 8, August 2018, E-ISSN: 2222-6990 @ 2018 HRMARS

Cassidy, J., Garrett, S. D., Maxfield, P., \& Patchett, C. (2009). Literacy coaching: Yesterday, Today and Tomorrow. Literacy Coaching: Research and Practice, 15-27. Retrieved from http://connection.ebscohost.com/c/articles

Cassidy, J., Montalvo Valadez, C., Dee Garrett, S., \& Barrera IV, E. S. (2010). Adolescent and Adult Literacy: What's Hot, What's Not. Journal of Adolescent \& Adult Literacy, 53(6), 448-456. https://doi.org/10.1598/JA

Cassidy, J., \& Ortlieb, E. (2013). The Evolution of What's Hot in Literacy, 1(2).

Center for the Use of Research and Evidence in Education (CUREE). (2005). Mentoring and Coaching CPD Capacity Building Project (2004-2005): National Framework for Mentoring and Coaching. London: CUREE. Retrieved from http://www.curee.co.uk/files

Center for the Use of Research and Evidence in Education (CUREE). (2012). Understanding What Enables High Quality Professional Learning. A Report on Research Evidence. Centre for the Use of Research Evidence in Education (CUREE). London, UK. Retrieved from www.curee.co.uk

Charner, I., \& Medrich, E. (2017). Educator-Centered Instructional Coaching: What the Research Says. Retrieved from https://www.fhi360.org/sites/default/files

Coburn, C. E., \& Woulfin, S. L. (2012). Reading Coaches and the Relationship Between Policy and Practice. Reading Research Quarterly, 47(1), 5-30. https://doi.org/10.1002/RRQ.008

Cohen, D. K., \& Hill, H. C. (1998). Instructional Policy and Classroom Performance: The Mathematics Reform in California. CPRE Research Reports Series RR-39. Retrieved from http://repository.upenn.edu/cpre_researchreports/4

Colbert, J. A., Brown, R. S., Choi, S., \& Thomas, S. (2008). An Investigation of the Impacts of TeacherDriven Professional Development on Pedagogy and Student Learning. Source: Teacher Education Quarterly Research Strategies and Professional Development, 35(2), 135-154. Retrieved from http://www.jstor.org

Cornett, J., \& Knight, J. (2009). Research on Coaching. In Coaching: Approaches and perspectives (pp. 192-216). Retrieved from https://resources.corwin.com/sites

Costa, A. L., \& Garmston, R. J. (1994). Cognitive coaching : A Foundation for Renaissance Schools. Christopher-Gordon Publishers. Retrieved from https://books.google.com.my

Creasy, J., \& Paterson, F. (2005). Leading Coaching in Schools. Leading Practice Seminar Series. London: National College for School Leadership.

Darling-Hammond, L., \& McLaughlin, M. W. (1995). Policies that Support Professional Development in an Era of Reform. Phi Delta Kappan, 76(8), 597-604.

Darling-Hammond, L., Wei, R. C., Andree, A., Richardson, N., \& Orphanos, S. (2009). Professional Learning in the Learning Profession: A Status Report on Teacher Development in the United States and Abroad. Oxford. Retrieved from https://edpolicy.stanford.edu/sites

Department for Education and Skills (DfES). (2003). Sustaining improvement: A suite of modules on Coaching, Running networks and Building capacity. DfES. London: DfES. Retrieved from http://dera.ioe.ac.uk/8848/7/DfES 0565-2003G_Redacted.pdf

Desimone, L. M., \& Pak, K. (2017). Instructional Coaching as High-Quality Professional Development. Theory Into Practice, 56(1), 3-12. https://doi.org/10.1080/00405841.2016.1241947

Deussen, T., Coskie, T., Robinson, L., \& Autio, E. (2007). “Coach" Can Mean Many Things: Five Categories of Literacy Coaches in Reading First. REL Northwest (Vol. 5). Retrieved from http://www.education.ucf.edu/mirc/Research/Coach Can Mean.pdf

Dewitt, P. (2014). 5 Reasons We Need Instructional Coaches - Peter DeWitt's Finding Common 
INTERNATIONAL JOURNAL OF ACADEMIC RESEARCH IN BUSINESS AND SOCIAL SCIENCES Vol. 8, No. 8, August 2018, E-ISSN: 2222-6990 @ 2018 HRMARS

Ground - Education Week. Retrieved July 16, 2018, from http://blogs.edweek.org

Edutopia. (2008). Why Is Teacher Development Important?: Because Students Deserve the Best. Retrieved August 10, 2017, from https://www.edutopia.org

Elish-Piper, L., \& L'Allier, S. K. (2011). Examining the Relationship between Literacy Coaching and Student Reading Gains in Grades K-3. The Elementary School Journal, 112(1), 83-106. Retrieved from http://www.jstor.org/stable/10.1086/660685

Emery, H. (2013). A global study of primary English teachers' qualifications, training and career development. British Council ELT Research Papers Volume 1. Retrieved from http://englishagenda.britishcouncil.org/sites/ec/files/British Council WEB pdf_0.pdf

Fielden, S. (2005). Literature review : coaching effectiveness - a summary. NHS Leadership Centre, 23.

Fullan, M. (2007). The New Meaning of Educational Change. Routledge. Retrieved from https://books.google.com.my/books?id=dvc84eFzKkkC\&source=gbs_navlinks_s

Gallucci, C., DeVoogt Van Lare, M., Yoon, I. H., \& Boatright, B. (2010). Instructional coaching: Building theory about the role and organizational support for professional learning. American Educational Research Journal, 47(4), 919-963. https://doi.org/10.3102/0002831210371497

Ganser, T. (2000). An Ambitious Vision of Professional Development for Teachers. NASSP Bulletin, 84(618), 6-12.

Garmston, R. (1987). How Administrators Support Peer Coaching. Educational Leadership, 44(5), 18-26. Retrieved from http://www.ascd.org/ASCD/pdf/journals/ed_lead/el_198702_garmston.pdf

Guskey, T. R. (2003, December). Analyzing Lists of the Characteristics of Effective Professional Development to Promote Visionary Leadership. NASSP Bulletin, 87(637), 4-22.

Hamlin, R. G., Ellinger, A. D., \& Beattie, R. S. (2008). The emergent 'coaching industry': a wake-up call for HRD professionals. Human Resource Development International, 11(3), 287-305. https://doi.org/10.1080/13678860802102534

Hassel, E. (1999a). Professional Development : Learning From the Best. A Toolkit For Schools and Districts based on the National Awards Program for Model Professional Development. Independent School. North Central Regional Educational Laboratory. Retrieved from http:www.learningpt.org/pdfs/pd/1ftb.pdf

Hassel, E. (1999b). Professional Development : Learning From the Best. Independent School. Retrieved from http:www.learningpt.org/pdfs/pd/1ftb.pdf

Hattie, J. (2012). Visible Learning for Teachers: Maximizing Impact on Learning. New York: Routledge. Retrieved from https://books.google.com.my

Hazri, J., Nordin, A. R., Reena, R., \& Abdul Rashid, M. (2007). Teacher Professional Development in Malaysia: Issues and Challenges. In Africa-Asia University Dialogue for Educational Development Network (pp. 85-102). Retrieved from http://aadcice.hiroshimau.ac.jp/e/publications/sosho4_2-08.pdf

Heineke, S. F. (2013). Coaching Discourse: Supporting Teachers' Professional Learning. The Elementary School Journal, 113(3), 409-433. https://doi.org/10.1086/521238

Hunt, C. S., \& Handsfield, L. J. (2013). The emotional landscapes of literacy coaching: Issues of identity, power, and positioning. Journal of Literacy Research, 45(1), 47-86. https://doi.org/10.1177/1086296X12469969

International Coach Federation (ICF). (2005). Frequently asked questions about coaching. Retrieved 
INTERNATIONAL JOURNAL OF ACADEMIC RESEARCH IN BUSINESS AND SOCIAL SCIENCES Vol. 8, No. 8, August 2018, E-ISSN: 2222-6990 @ 2018 HRMARS

from http://www.coachfederation.org/

International Reading Association. (2004). Standards for Reading Professionals-Revised 2003. International Reading Association, Inc.

Ippolito, J. (2010). Three Ways That Literacy Coaches Balance Responsive and Directive Relationships with Teachers. The University of Chicago Press Journals, 111(1), 164-190. https://doi.org/10.1086/653474

Israel, M., Kamman, M. L., McCray, E. D., \& Sindelar, P. T. (2014). Mentoring in Action : The Interplay Among Professional Assistance, Emotional Support, and Evaluation. Exceptional Children, 81(1), 45-63. https://doi.org/10.1177/0014402914532231

Jao, L. (2013). Peer Coaching as a Model for Professional Development in the Elementary Mathematics Context: challenges, needs and rewards. Policy Futures in Education, 11(3), 2013. https://doi.org/10.2304/pfie.2013.11.3.290

Joo, B.-K. (Brian), Sushko, J. S., \& McLean, G. N. (2012). Multiple Faces of Coaching : Manager-ascoach , Executive Coaching , and Formal Mentoring. Organization Development Journal, 30(1), 19-38. https://doi.org/10.1080/13678860802102534

Joyce, B., \& Showers, B. (1980). Improving inservice training: The messages of research. Educational Leadership, 37(5), 379-385. Retrieved from http://www.eric.ed.gov

Joyce, B., \& Showers, B. (1996). The Evolution of Peer Coaching. Educational Leadership, 53(6), 1216.

Kaur, M. (2017). To recognise, realise and differentiate the learning needs of students. Pertanika Journal of Social Sciences and Humanities, 25(2), 503-510.

Kempton, J. (2013). To teach, to learn: more effective continuous professional development for teachers. London: CentreForum. Retrieved from http://www.centreforum.org

Kennedy, M. M. (2016). How Does Professional Development Improve Teaching? Review of Educational Research, 86(4), 945-980. https://doi.org/10.3102/0034654315626800

Kent, A. M. (2004). Improving Teacher Quality through Professional Development. Education, 14(3), 427-435.

King, D., Neuman, M., Pelchat, J., Potochnik, T., Rao, S., \& Thompson, J. (2014). Instructional Coaching: Professional Development Strategies that Improve Instruction. Annenberg Institute for School Reform, 1-17. Retrieved from www.annenberginstitute.org

Knight, J. (2004). Instructional coaches make progress through partnership: Intensive support can improve teaching. National Staff Development Council, 25(2), 32-37. https://doi.org/10.1080/03004270385200031

Knight, J. (2007). Instructional Coaching: A Partnership Approach to Improving Instruction. Thousand Oaks, CA: Corwin Press. Retrieved from https://books.google.com.my

Knight, J. (2009). Coaching the Key to Translating Research into Practice Lies in Continuous, JobEmbedded Learning with Ongoing Support. JSD, 30(1). Retrieved from http://rapps.pbworks.com/f/NSDC-Coaching.pdf

Kraft, M. A., Blazar, D., \& Hogan, D. (2018). The Effect of Teacher Coaching on Instruction and Achievement: A Meta-Analysis of the Causal Evidence. Review of Educational Research, XX(X), 003465431875926. https://doi.org/10.3102/0034654318759268

Kretlow, A. G., Cooke, N. L., \& Wood, C. L. (2012). Using In-Service and Coaching to Increase Teachers' Accurate Use of Research-Based Strategies. Remedial and Special Education, 33(6), 348-361. https://doi.org/10.1177/0741932510395397 
INTERNATIONAL JOURNAL OF ACADEMIC RESEARCH IN BUSINESS AND SOCIAL SCIENCES Vol. 8, No. 8, August 2018, E-ISSN: 2222-6990 @ 2018 HRMARS

L'Allier, S., Elish-Piper, L., \& Bean, R. M. (2010). What Matters for Elementary Literacy Coaching? Guiding Principles for Instructional Improvement and Student Achievement. The Reading Teacher, 63(7), 544-554. https://doi.org/10.1598/RT.63.7.2

Li, B., \& Chan, S. (2007). Coaching as a means for enhancing English-language teachers' professional development: a case study. Journal of In-Service Education, 33(3), 341-358. https://doi.org/10.1080/13674580701486952

Lieberman, A. (1995). Practices That Support Teacher Development. Phi Delta Kappan, 76(8), 591596. Retrieved from http://search.ebscohost.com

Lloyd, C. M., \& Modline, E. L. (2012). Coaching as a Key Component in Teachers' Professional Development: Improving Classroom Practices in Head Start Settings. OPRE Report2012-4.

Lowenhaupt, R., Mckinney, S., \& Reeves, T. (2014). Coaching in context : the role of relationships in the work of three literacy coaches. Professional Development in Education, 40(5), 740-757. https://doi.org/10.1080/19415257.2013.847475

Matsumura, L. C., Garnier, H. E., Correnti, R., Junker, B., \& DiPrima Bickel, D. (2010). Investigating the Effectiveness of a Comprehensive Literacy Coaching Program in Schools with High Teacher Mobility. The Elementary School Journal, 111(1), 35-62. https://doi.org/10.1086/653469

Matsumura, L. C., Garnier, H. E., \& Resnick, L. B. (2010). Implementing Literacy Coaching. Educational Evaluation and Policy Analysis, 32(2), 249-272. https://doi.org/10.3102/0162373710363743

Matsumura, L. C., Sartoris, M., Bickel, D. D., \& Garnier, H. E. (2009). Leadership for Literacy Coaching: The Principal's Role in Launching a New Coaching Program. Educational Administration Quarterly, 45(5), 655-693. https://doi.org/10.1177/0013161X09347341

Medrich, E. A., Fitzgerald, R., \& Skomsvold, P. (2013). Instructional Coaching and Student Outcomes : Findings from a Three Year Pilot Study. Berkeley.

Michael, A. (2008, August). Mentoring and coaching. Topic Gateway Series. Retrieved from http://www.cimaglobal.com/Documents/ImportedDocuments

Ministry of Education (Malaysia). (2013). Malaysia Education Blueprint 2013-2015 (Preschool to Post-Secondary Education). Putrajaya: Ministry of Education Malaysia.

Mohd Hilmi, A., \& Jamil, A. (2017). Persepsi Guru Terhadap Program Pembimbing Pakar Peningkatan Sekolah (SISC+). In Seminar on Transdisciplinary Education (STEd2017) (pp. 198205). Retrieved from https://sted2017.files.wordpress.com

National College for Teaching \& Leadership. (2013). Mentoring and Coaching: Advanced Skills and Application. National College for Teaching \& Leadership. Crown. Retrieved from https://nationalcollege.org.uk/transfer/open/mentoring-and-coaching-advanced-skills

National Staff Development Council. (2001). National Staff Development Council's Standards for Staff Development. Oxford.

Nelson, B. S., \& Hammerman, J. K. (1996). Reconceptualizing Teaching: Moving toward the Creation of Intellectual Communities of Students, Teachers, and Teacher Educators. In McLaughlin, M. Wallin., \& I. Oberman (Eds.), Teacher Learning: New Policies, New Practices. The Series on School Reform (p. 252). New York: Teachers College Press.

Neufeld, B., \& Roper, D. (2003). Expanding the Work: Year II of Collaborative Coaching and Learning in the Effective Practice Schools. Cambridge, MA: Education Matters, Inc.

Neuman, S. B., \& Wright, T. (2010). Promoting Language and Literacy Development for Early Childhood Educators: A Mixed-Methods Study of Coursework and Coaching. Elementary School 
INTERNATIONAL JOURNAL OF ACADEMIC RESEARCH IN BUSINESS AND SOCIAL SCIENCES Vol. 8, No. 8, August 2018, E-ISSN: 2222-6990 @ 2018 HRMARS

Journal, 111(1), 63-86.

Ng, K. C., Choong, L. K., Norizan, A., Lam, K. K., \& Siti Mariam, S. (2014). Tinjauan Awal Persepsi School Improvement Specialist Coach (SISC+): Perkembangan, Cabaran dan Ekspektasi. Academia, 1-15. Retrieved from https://www.academia.edu/13583759

OECD. (2009). Creating Effective Teaching and Learning Environments: First Results from TALIS - The Professional Development of Teachers. Retrieved from https://www.oecd.org/berlin/43541636.pdf

Pang, E. L. L., \& Wray, D. (2017). A Framework on Exploring Primary School English Language Teachers' Perceptions of their Continuing Professional Development in Malaysia. Athens Journal of Education, 4(1), 16-19. Retrieved from http://www.athensjournals.gr/education

Poglinco, S. M., Bach, A. J., Hovde, K., Rosenblum, S., Saunders, M., \& Supovitz, J. A. (2003). The Heart of the Matter : The Coaching Model in America's Choice Schools. Philadelphia: Consortium for Policy Research in Education, University of Pennsylvania Graduate School of Education.

Pomerantz, F., \& Pierce, M. (2013). "When Do We Get To Read?" Reading Instruction and Literacy Coaching in a "Failed" Urban Elementary School. Reading Improvement, 50(3), 101-117. Retrieved from http://search.ebscohost.com

Porche, M. V., Pallante, D. H., \& Snow, C. E. (2012). Professional Development for Reading Achievement: Results from the Collaborative Language and Literacy Instruction Project (CLLIP). The Elementary School Journal, 112(4), 649-671. https://doi.org/10.1086/665008

Radzuwan, A. R., Shireena Basree, A. R., \& Kamariah, Y. (2017). Reforms in the policy of English language teaching in Malaysia. Policy Futures in Education, 15(1), 100-112. https://doi.org/10.1177/1478210316679069

Rand Education. (2012). Teachers Matter: Understanding Teachers' Impact on Student Achievement. Retrieved March 20, 2017, from http://www.rand.org/education/projects/measuring-teacher-effectiveness/teachersmatter.html

Rogers, J. (2008). Coaching Skills: A Handbook. McGraw-Hill Education. Retrieved from http://books.google.com/books?hl=en\&lr=\&id=xorJ9uxnZ_8C\&pgis=1

Sailors, M., \& Price, L. (2015). Support for the Improvement of Practices through Intensive Coaching (SIPIC): A model of coaching for improving reading instruction and reading achievement. Teaching and Teacher Education, 45, 115-127. https://doi.org/10.1016/j.tate.2014.09.008 Sailors, M., \& Shanklin, N. L. (2010). Growing Evidence to Support Coaching in Literacy and Mathematics. The Elementary School Journal, 111(1), 1-6.

Sarabiah, J., \& Zamri, M. (2016). Tanggapan, Amalan dan Keberkesanan Bimbingan Pegawai SISC+ dari Perspektif Guru Bahasa Melayu. In Prosiding Seminar Pascasiswazah Pendidikan Kesusasteraan Melayu Kali Kelima (pp. 393-416). Bangi: Penerbitan Fakulti Pendidikan, Universiti Kebangsaan Malaysia.

Senom, F., Razak Zakaria, A., \& Sharatol Ahmad Shah, S. (2013). Novice Teachers' Challenges and Survival: Where do Malaysian ESL Teachers Stand? American Journal of Educational Research, 1(4), 119-125. https://doi.org/10.12691/education-1-4-2

Showers, B., Joyce, B., \& Bennett, B. (1987). Synthesis of Research on Staff Development: A Framework for Future Study and a State-of-the-Art Analysis. Educational Leadership, 45(3), 7787. Retrieved from http://0-search.ebscohost.com. 
INTERNATIONAL JOURNAL OF ACADEMIC RESEARCH IN BUSINESS AND SOCIAL SCIENCES Vol. 8, No. 8, August 2018, E-ISSN: 2222-6990 @ 2018 HRMARS

Smith, R. E. (2009). Human Resources Administration : A School-Based Perspective. New York: Eye on Education Inc. https://doi.org/ISBN-978-1-5966-7089-1

Smith, R., \& Lynch, D. (2014). Coaching and Mentoring : A Review of Literature as it relates to Teacher Professional Development. International Journal of Innovation, Creativity and Change, 1(4).

Snow, C. E., Griffin, P., \& Burns, M. S. (2005). Knowledge to support the teaching of reading: Preparing teachers for a changing world. The Jossey-Bass education series. Jossey-Bass.

Sprick, R. S. (2006). Coaching Classroom Management : A Toolkit for Administrators and Coaches. Pacific Northwest Pub.

Suzalin, Z. S., Ilda Salwani, A. H., \& Noorazam, A. N. (2014). The Success of Establishment of the Professional Learning Communities in One School in the District of Port Dickson through the Learning Walks Strategy : From the Point of View of the SISC+. In World Association Of Lesson Studies International Conference 2014. Bandung, Indonesia.

Taylor, R. T., Zugelder, B. S., \& Bowman, P. (2013). Literacy Coach Effectiveness: The Need for Measurement. International Journal of Mentoring and Coaching in Education, 2(1), 34-46. https://doi.org/10.1108/20466851311323078

The Wallace Foundation. (2013). THE SCHOOL PRINCIPAL AS LEADER: GUIDING SCHOOLS TO BETTER TEACHING AND LEARNING.

Toll, C. A. (2014). The Literacy Coach's Survival Guide : Essential Questions and Practical Answers (2nd ed.). United States: International Literacy Association. Retrieved from https://www.bookdepository.com/The-Literacy-Coachs-Survival-Guide-Cathy-A.-Toll

van Nieuwerburgh, C. (2012). Coaching in Education: Getting Better Results for Students, Educators, and Parents. New York: Karnac Books. Retrieved from https://books.google.com.my

Vanderburg, M., \& Stephens, D. (2011). The Impact of Literacy Coaches: What Teachers Value and How Teachers Change. The Elementary School Journal, 111(1), 141-163.

Vikraman, S. S., Mansor, A. N., \& Hamzah, M. I. . (2017). Mentoring and Coaching Practices for Beginner Teachers-A Need for Mentor Coaching Skills Training and Principal's Support. Creative Education, 08(01), 156-169. https://doi.org/10.4236/ce.2017.81013

Weiss, T., \& Kolberg, S. (2003). Coaching Competencies and Corporate Leadership. In ST Lucie Press. West, L., \& Staub, F. C. (2003). Content-focused Coaching: Transforming Mathematics Lessons. Portsmouth: Heinemann. Retrieved from https://books.google.com.my

Westman, L. (2016). Instructional Coaching In 20 Seconds Or Less. Retrieved July 16, 2018, from https://lisawestman.com/2016/12/16/instructional-coaching-in-20-seconds-or-less/

Wilkins, B. M. (2000). A grounded theory study of personal coaching. Doctoral dissertation, ProQuest Information \& Learning. Retrieved from http://psycnet.apa.org/record/2000-95021108

Wong, A. T., \& Premkumar, K. (2007). An Introduction to Mentoring Principles, Processes, and Strategies for Facilitating Mentoring Relationships at a Distance. Retrieved from http://citeseerx.ist.psu.edu/viewdoc/download?doi=10.1.1.560.8409\&rep=rep1\&type=pdf

Wong, W. L., \& Ching, H. K. (2015). iOS app for Differentiated Lesson Plans in Malaysian English Secondary Classrooms. In EAMELT. Kongu Engineering College, Erode, Tamil Nadu, India. Retrieved from https://www.researchgate.net/profile/Ching_Hei_Kuang/publication

Yoon, K. S., Duncan, T., Lee, S. W.-Y., Scarloss, B., \& Shapley, K. L. (2007). Reviewing the evidence on how teacher professional development affects student achievement (Issues \& Answers Report, 
INTERNATIONAL JOURNAL OF ACADEMIC RESEARCH IN BUSINESS AND SOCIAL SCIENCES

Vol. 8, No. 8, August 2018, E-ISSN: 2222-6990 @ 2018 HRMARS

REL 2007-No. 033). American Educational Research Journal. Washington D.C. https://doi.org/10.3102/0002831208328088

Zein, S. (2016). Factors affecting the professional development of elementary English teachers. Professional Development in Education, 42(3), 423-440.

https://doi.org/10.1080/19415257.2015.1005243 